\title{
The Interplay between Apelin/APJ System and Renin Angiotensin System in Protection Against Cold Restraint Stress Induced Gastric Ulcers in Adult Male Rats
}

\author{
NANCY F. SAMIR, M.D.*; FATMA E. IBRAHIM, M.D.* and LAILA A. RASHED, M.D.** \\ The Departments of Physiology* and Biochemistry**, Faculty of Medicine, Cairo University, Egypt
}

\begin{abstract}
Background: Activation of Renin Angiotensin System (RAS) is one of the main mechanisms involved in the development of stress induced gastric ulcers.

Aim of the Study: This study aimed to examine the effect of inhibitors of RAS in protection against stress-induced gastric ulcers and the interplay between RAS and apelin/APJ system in gastric protection.
\end{abstract}

Material and Methods: Twenty-four adult male rats were divided into 4 groups: Control, Cold Restraint Stress (CRS), Angiotensin Converting Enzyme (ACE) inhibitor + CRS and Angiotensin II receptor type 1 (AT-1) blocker + CRS. Ulcer index, $\mathrm{PH}$, acidity and mucin content of gastric fluid were measured. MDA, NO, PGE2, apelin level, COX-2 and Angiotensin 1-7 gene expression assessment were done. Gastric tissues were assessed histopathologically.

Results: Pre-treatment of rats with either capoten or micardis for 14 days prior to CRS significantly reduced ulcer index, gastric acidity, MDA and COX-2 expression; while $\mathrm{PH}$, gastric acidity, mucin content, NO, PGE2, gastric apelin level and Angiotensin 1-7 gene expression were significantly elevated.

Conclusion: Our findings suggest the integration between apelin/APJ system and RAS in protection against gastric ulceration.

Key Words: Renin angiotensin system - Apelin - Angiotensin 1-7- Gastric stress ulcers.

\section{Introduction}

STRESS induced gastric ulceration is a common complication following various stressors such as anxiety, hemorrhagic shock, burns, sepsis and trauma. Multiple events share in the pathogenesis of stress induced gastric mucosal injury including reduced mucosal blood flow, back diffusion of the acidic gastric juice to the gastric mucosa, inhibition

Correspondence to: Dr. Nancy F. Samir, The Department of Physiology, Faculty of Medicine, Cairo University, Egypt of mucosal prostaglandin synthesis, reduction of mucin, oxidative stress and inflammation [1]

Angiotensin II (Ang II), the main active component of RAS, is one of the major factors involved in the pathogenesis of stress induced gastric ulceration through activation of many oxidative and inflammatory pathways and reduction of gastric blood flow. These actions are mediated via binding to angiotensin 1 receptors (AT-1) [2] .

Hypertension and its underlying pathology are considered to be high risk factors for induction of gastric ulcers, so, it may be of a critical value to determine the optimal antihypertensive drug that will reduce such risk [3]. Angiotensin converting enzyme-1 (ACE-1) inhibitors and AT-1 blockers are two widely used antihypertensive drugs. They act via inactivation of RAS; hence they are suggested to have a protective effect against stress induced gastric ulcers.

Previous studies demonstrated that ACE-1 inhibitors, via enhancing production of endogenous prostaglandins and nitric oxide protect gastric mucosa against indomethacin induced gastric ulcers [4]. Furthermore, AT-1 blockers were found to have a gastroprotective role against indomethacin and Cold Restraint Stress (CRS) induced gastric ulcers in rat models [5].

Angiotensin 1-7 (Ang 1-7) is an active metabolite of RAS produced by the action of ACE2 on Ang II. It was found to counteract the effects of Ang II on stomach by binding to MAS receptors and improving gastric blood flow [6]. These findings draw attention to the potential preventive role of Ang 1-7 against stress induced gastric lesions. 
Apelin receptor (APJ) and apelin, are plentifully distributed in the gastrointestinal tract (GIT) [7] It was established that they play key roles in regulation of many gastrointestinal and metabolic functions [8] . A previous study by Nimet et al., [9] showed that F13A, an APJ receptor antagonist, augmented the gastric mucosal injury induced by water immersion and restraint stress in rats. These results provide a strong evidence for the gastroprotective effect of apelin.

Previous cardiovascular studies revealed an antagonistic relationship between Apelin/APJ system and RAS. Cardiac apelin was shown to be upregulated by blocking RAS. Furthermore, apelin was found to upregulate ACE2 expression, and antagonize AT $1 \mathrm{R}$ signaling in failing hearts via a heterodimerization of APJ and AT1R [10]. However, the interplay between apelin/APJ system and RAS system in protection against stress induced gastric ulcers was not previously investigated.

Our work was designed to examine the gastroprotective effects of the ACE-1 inhibitor (captopril) and the AT-1 blocker (telmisartan) against cold restraint stress in male rats. Moreover, we highlighted the crosstalk between apelin/APJ system and RAS in gastroprotection against cold induced stress ulcers.

\section{Material and Methods}

Twenty four adult male albino rats weighing $150-180 \mathrm{gm}$ were included in this study. Rats were bought from the Animal House of Faculty of Medicine, Cairo University, Egypt and were located in a room at $23^{\circ} \mathrm{C}$ on an alternating $12: 12 \mathrm{~h}$ light-dark cycle and had free access to food and water. This work was carried out in September, 2017 in the Physiology Department, Faculty of Medicine, Cairo University.

Rats were randomly divided into four groups of six animals each. Group 1 (control group): Rats were pretreated with $2 \mathrm{ml} / \mathrm{kg} /$ day saline in a single oral dose for 14 days; group 2 (cold restraint stress group; CRS). Group 3: ACE inhibitor (capoten) + CRS group, the rats were pretreated with capoten $(10 \mathrm{mg} / \mathrm{kg} /$ day in a single oral dose) for 14 days prior to ulcer induction [5]. Group 4 (micardis + CRS group): Rats were pretreated with micardis $(10 \mathrm{mg} / \mathrm{kg} /$ day in a single oral dose) for 14 days prior to ulcer induction [5] . Captopril (capoten), Telmisartan (micardis) tablets were purchased from multipharma (Cairo, Egypt). Ketamine was purchased from sigma (Cairo, Egypt).
At the end of experiment, rats of all groups were deprived of food for $24 \mathrm{~h}$ and were housed in separate cages to diminish coprophagia but free water drinking was permitted except for the last hour before pyloric ligation. Pyloric ligation was applied to rats of all groups as per Debnath et al., [11], for further collection of gastric fluid. Rats were anesthetized by (intraperitoneal injection of ketamine, $12 \mathrm{mg} / \mathrm{kg}$ ) then their abdomens were opened, and thread knots were tied around the pyloric sphincters. The abdomens were closed with interrupted sutures and garamycin cream was applied over the wound. The rats were retained in separate cages and permitted for recovery. Afterwards, rats of all groups except control group were exposed to CRS.

Acute gastric ulcers were induced by immobilizing the rats via tethering the fore and hind limbs separately on a wooden board with an adhesive tape. Lastly, all the rats were reserved at $4-7^{\circ} \mathrm{C}$ for two hours [12].

Lastly, all animals were sacrificed by cervical dislocation and the stomachs were removed after clamping of the lower ends of both the esophagus and pylorus. The gastric fluid was collected via an incision through the greater curvature, for assessment of its $\mathrm{PH}$, free and total acidity and mucin content. The mucosa was exposed and thoroughly washed with saline, then, it was placed on a flat wooden board for gross assessment of gastric lesions and ulcer scoring. Gastric tissues were preserved for further assessment of Malondialdyhyde (MDA), Nitric Oxide (NO), Prostaglandine E2 (PGE2), apelin level, Cyclo-Oxygenase 2 (COX2) gene expression, Angiotensin 1-7 (Ang 1-7) gene expression and histopathological assessment.

Assessment of ulcer index: The scoring of ulcer severity is demonstrated in (Table 1). Ulcer index is the summation of the number of ulcers multiplied by their score per stomach.

Ulcer index $=1 \mathrm{X}($ no. of ulcer of score 1$)+2$ $X$ (No. of ulcer of score 2$)+3 X$ (No. of ulcer of score 3$)+4 X$ (no. of ulcer of score 4$)$ [13]

Histopathological examination: The gastric tissue samples were fixed in $10 \%$ formalin, inserted in paraffin wax, sectioned then stained with hematoxylin and eosin for histopathological study beneath the light microscope.

Measurement of gastric fluid acidity, $\mathrm{pH}$ and mucin content: The gastric content was collected in a centrifuge tube and centrifuged for 10 minutes at $1,000 \mathrm{rpm}$. The $\mathrm{pH}$ of this solution was recorded 
with the help of a pH meter [14] and the mucin concentration was measured in the supernatant [15]. One $\mathrm{mL}$ of supernatant was diluted up to $10 \mathrm{~mL}$ with distilled water then it was titrated against $0.01 \mathrm{~N} \mathrm{NaOH}$ using Topfer's reagent until the solution was colored into orange. The volume of $\mathrm{NaOH}$ required was considered as an equivalent to the free acidity. Titration was continued till solution got back pink. The quantity of $\mathrm{NaOH}$ needed was considered as a correspondent to the total acidity [16].

Measurement of gastric MDA level: Gastric tissue sample was homogenized in $1 \mathrm{~mL}$ PBS, $\mathrm{pH}$ 7.0, with micropestle in a microtube. $20 \%$ TCA was added to tissue homogenate to precipitate the protein and centrifuged. Supernatants were gathered and Thiobarbituric Acid (TBA) solution was added to them. After boiling for 10 minutes in water bath, the absorbance was calculated and via the standard curve the concentration of MDA was measured [17].

Measurement of gastric no level: The level of NO was assessed by a colorimetric technique according to the method of Montgomery and Dymock [18]. This technique depends on that, in acid medium and in the existence of nitrite the formed nitrous acid diazotize sulphanilamide, the product is coupled with N-(1-naphthyl) ethylenediamine. The resulting azo dye has a bright reddish- purple color which can be measured at $540 \mathrm{~nm}$. Then no level was calculated via the standard curve.

Measurement of gastric PGE2: The evaluation of gastric PGE2 content is done via the competitive inhibition enzyme immunoassay procedure. The micro titer plate has been pre-coated with a goatanti-rabbit antibody. Standards or samples are added to the suitable micro titer plate wells with a specific antibody for PGE2 and Horseradish Peroxidase (HRP) conjugated PGE2 and incubated, afterward substrate solutions are added to each well. The reaction is completed by adding the sulphuric acid solution and the color alteration is measured spectrophotometrically at a wavelength of $450 \mathrm{~nm}$ [19].

Measurement of gastric apelin level: The assay of apelin level employs the quantitative sandwich enzyme immunoassay technique. Antibody specific for APLN has been pre-coated onto a microplate. Standards and samples are pipetted into the wells and any APLN present is bound by the immobilized antibody. After removing any unbound substances, a biotin-conjugated antibody specific for APLN is added to the wells. After washing, avidin conjugated Horseradish Peroxidase (HRP) is added to the wells. Following a wash to remove any unbound avidin-enzyme reagent, a substrate solution is added to the wells and color develops in proportion to the quantity of APLN bound in the initial step. Then the color intensity is measured spectrophotometrically at a wavelength of $450 \mathrm{~nm}$. The concentration of apelin is then determined by comparing the OD of the samples to the standard curve [20].

Measurement of gastric Ang 1-7 and COX-2 gene expression by quantitative real-time polymerase chain reaction ( $q R T-P C R$ ): Ang 1-7 and COX2 gene expression were detected using (qRT-PCR). Briefly, total RNA was extracted from frozen tissue samples using TRIzol (Invitrogen) following the manufacturer's protocol extracted RNA and was quantified by spectrophotometer. 2ug of total RNA were reverse transcribed in $0.05 \mathrm{M}$ Tris- $\mathrm{HCl} \mathrm{pH}$ $8.3,40 \mathrm{mM} \mathrm{KCl}, 7 \mathrm{mM} \mathrm{MgCl} 2$ buffer containing $0.05 \mathrm{ug}$ of random hexamers, $1 \mathrm{mM}$ dNTPs mix, 0.05U/1 RNase inhibitor and 200U/1 murine leukemia virus reverse transcriptase M-MLV. Samples were incubated for $10 \mathrm{~min}$ at $70 \mathrm{C}$ and then $60 \mathrm{~min}$ at $37 \mathrm{C}$. Inactivation of the reverse transcriptase was achieved by heating the samples at $95 \mathrm{C}$ for 10min. Real-time RT-PCR for quantitative assessment of mRNA expression was performed on step one plus, reaction contained SYBR Green Master Mix (Applied Biosystems, USA), gene-specific forward and reverse primers (10 M) MNA and nuclease-free water. the sequences of PCR primer pairs used for each gene are shown in (Table 2). With cycling conditions $\left(10 \mathrm{~min}\right.$ at $95^{\circ} \mathrm{C}$ followed by 40 cycles of $15 \mathrm{~s}$ at $95^{\circ} \mathrm{C}$ and $60 \mathrm{~s}$ at $60^{\circ} \mathrm{C}$ ). The level of expression of each target gene was normalized relative to the expression of GAPDH mRNA in that sample using the $\Delta \mathrm{Ct}$ method. Relative differences in gene expression among groups were determined using the comparative $\mathrm{Ct}(\Delta \Delta \mathrm{Ct})$ method and fold expression was calculated as $2 \Delta \Delta \mathrm{Ct}$, where $\Delta \Delta \mathrm{Ct}$ represents $\Delta \mathrm{Ct}$ values normalized relative to the mean $\Delta \mathrm{Ct}$ of control samples [21]

\section{Statistical analysis:}

Analysis was performed with SPSS software package (Version 17). The data was expressed as mean $\pm \mathrm{SD}$, with a value of $p<0.05$ considered statistically significant. Statistical evaluation was performed by one-way analysis of variance (ANOVA) followed by post hoc test for multiple comparisons of means [22]. 
Table (1): Score of ulcer severity.

\begin{tabular}{|c|c|}
\hline Score & Features \\
\hline 0 & - No ulcer. \\
\hline 1 & $\begin{array}{l}\text { - Pin point ulcer and changes limited to superficial } \\
\text { layers of mucosa. }\end{array}$ \\
\hline 2 & - Ulcer less than $1 \mathrm{~mm}$ in size. \\
\hline 3 & - Ulcer more than $1 \mathrm{~mm}$ but less than $2 \mathrm{~mm}$ in sizes. \\
\hline 4 & - Ulcer more than $2 \mathrm{~mm}$ or perforation of ulcer. \\
\hline
\end{tabular}

Table (2): Primers of Angiotensin 1-7 and COX-2.

\begin{tabular}{ll}
\hline Angiotensin 1-7 & $\cdot$ Forward primer: 5'-TTCCCCCAAAGGC \\
& CAAGTCCCA-3 \\
& $\cdot$ Reverse primer: 5'-GAGGCTGCCCTGG \\
& CTTCTGTC-3 \\
& \\
COX-2 & Forward primer: 5'-GTGGGATGACGA \\
& GCGACTG-3 \\
& $\cdot$ Reverse primer: 5'-CCGTGTTCAAGG \\
& AGGATGG-3 \\
\hline
\end{tabular}

\section{Results}

Effect of pretreatment with capoten or micardis on ulcer index in rats subjected to CRS:

The results of the present work showed that ulcer index was significantly elevated $(p<0.001)$ in CRS group compared to control group. Both capoten and micardis administration for 14 days prior to ulcer induction; significantly reduced ulcer index compared to non treated CRS group $(p<$ $0.001)$. Worthwhile, we didn't notice any significant difference in ulcer index results neither between both drug groups nor between them and the control group. These results indicate that both drugs exerted marked protective effects against CRS (Table 3 ).

Effect of pretreatment with capoten or micardis on the the PH, acidity and mucin content of gastric fluid in rats subjected to CRS:

As summarized in (Table 3), CRS resulted in a significant reduction in the $\mathrm{PH}$ of gastric fluid and a significant elevation in the total and free gastric acidity $(p<0.001)$ compared to control group. On the other hand, pretreatment of rats with capoten or micardis showed a significant increase in $\mathrm{PH}$ and a significant attenuation of both total and free gastric acidity $(p<0.001)$ compared to non treated group. Interestingly, these parameters showed insignificant difference between micardis and capoten pretreated groups. Furthermore, there was no significant difference between the control group and both drugs groups.

Moreover, the mucin content of gastric fluid showed a significant reduction in CRS group com- pared to control group. A significant improvement in mucin content was noticed in both capoten and micardis groups compared to CRS group. This improvement was partial and there was still a significant difference between both drug groups and control group $(p<0.05)$. On the other hand, there was no significant difference between both drugs groups.

Effect of pretreatment with capoten or micardis on oxidative stress and inflammatory markers in gastric tissues of rats subjected to CRS:

As observed in Fig. (1), CRS induced a significant increase $(p<0.001)$ in MDA (marker of oxidative stress) compared to control group. On the other hand, the results showed a significant reduction $(p<0.001)$ in NO and PGE2 (anti-inflammatory markers) together with a significant increase $(\mathrm{p}<0.001)$ in COX2 gene expression in CRS group compared to control. Pretreatment of rats with either capoten or micardis before exposure to CRS resulted in a significant reduction $(p<0.001)$ in MDA and COX 2 gene expression leading them towards control. While NO and PGE2 results revealed a significant increase $(p<0.001)$ in pretreated groups compared to CRS non treated group. In spite of the significant improvement of oxidative stress and inflammatory makers measured in this study, we still observe a significant difference $(p<0.001)$ between drug groups and control. Again, comparing results of capoten with micardis group revealed no significant difference.

Effect of pretreatment with capoten or micardis on apelin level and angiotensin 1-7 gene expression in gastric tissues of rats subjected to CRS:

Fig. (2) showed that apelin level and Ang 1-7 gene expression were significantly decreased ( $p<$ 0.001) in CRS group compared to control. While pretreatment with either capoten or micardis; caused a significant increase $(p<0.001)$ in both parameters compared to CRS group. Interestingly, apelin level showed a non significant difference in both drug groups compared to control. However, Ang 1-7 gene expression was still significantly lower $(p<0.001)$ compared to control value. Lastly, results of both drug groups were incomparable.

\section{Histopathological changes in the studied groups:}

Both macroscopic and microscopic pictures of CRS group showed marked changes indicating gastric mucosal injury; while capoten and micardis pretreated groups, revealed evident protection against CRS as shown in Figs. $(3,4)$. 
Table (3): Effect of pre-treatment with capoten or micardis on ulcer index, $\mathrm{PH}$, gastric acidity and mucin content of the gastric fluid in rats subjected to CRS.

\begin{tabular}{|c|c|c|c|c|}
\hline Parameter & Control & CRS & Capoten + CRS & Micardis + CRS \\
\hline Ulcer index & $2.67 \pm 2.66$ & $32.67 \pm 9.03 *$ & $3.33 \pm 2.88 \#$ & $3 \pm 3.35 \#$ \\
\hline $\mathrm{PH}$ & $3.53 \pm 0.29$ & $1.43 \pm 0.28 *$ & $3.2 \pm 0.36 \#$ & $3.23 \pm 0.28 \#$ \\
\hline Total gastric acidity $(\mathrm{mEq} / \mathrm{L})$ & $17.73 \pm 1.896$ & $50.97 \pm 5.996^{*}$ & $23.62 \pm 3.84 \#$ & $24.45 \pm 3.11 \#$ \\
\hline Free gastric acidity $(\mathrm{mEq} / \mathrm{L})$ & $9.72 \pm 0.54$ & $21.35 \pm 3.93^{*}$ & $11.62 \pm 1.98 \#$ & $12.68 \pm 1.96 \#$ \\
\hline Mucin content ( $\mathrm{g} / \mathrm{g}$ tissue) & $3.53 \pm 0.29$ & $1.43 \pm 0.28^{*}$ & $3.02 \pm 0.31 \# \Delta$ & $2.99 \pm 0.29 \# \Delta$ \\
\hline
\end{tabular}

Values are represented as mean $\pm \mathrm{SD}(\mathrm{n}=6 /$ group$)$.

* : Means significantly different compared to control group $(p<0.001)$

\# : Means significantly different compared to CRS group $(p<0.001)$.

Means significantly different compared to control group $(p<0.05)$.
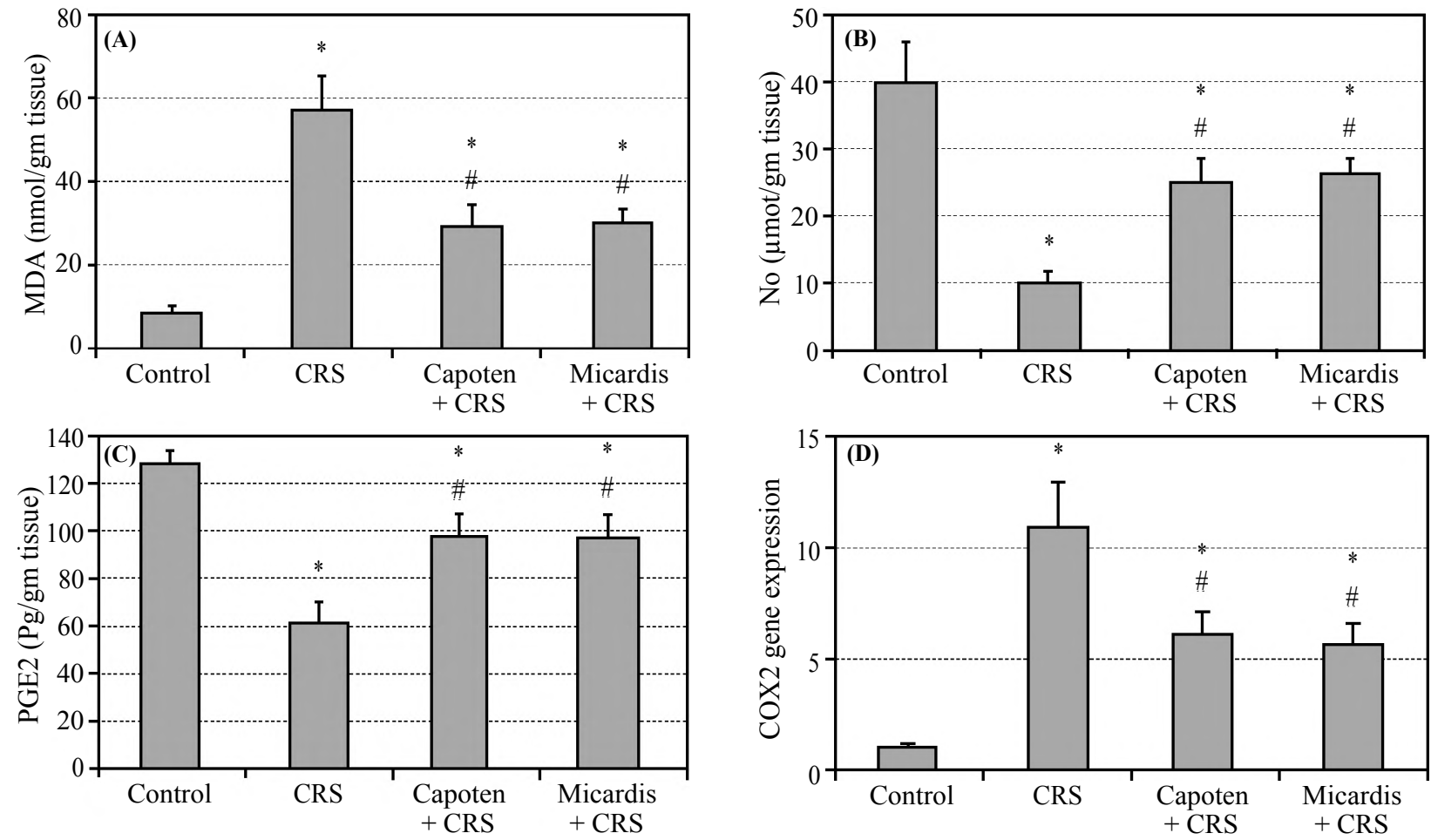

Fig. (1): (A): MDA (nmol/gm tissue). (B): NO ( $\mathrm{mal} / \mathrm{gm}$ tissue). (C): PGE2 (Pg/gm tissue). (D): COX2 gene expression in the four studied groups $(n=6)$.

Each vertical bar represents the mean \pm SD

*: Means significantly different compared to control group $(p<0.001)$.

\#: Means significantly different compared to CRS group $(p<0.001)$
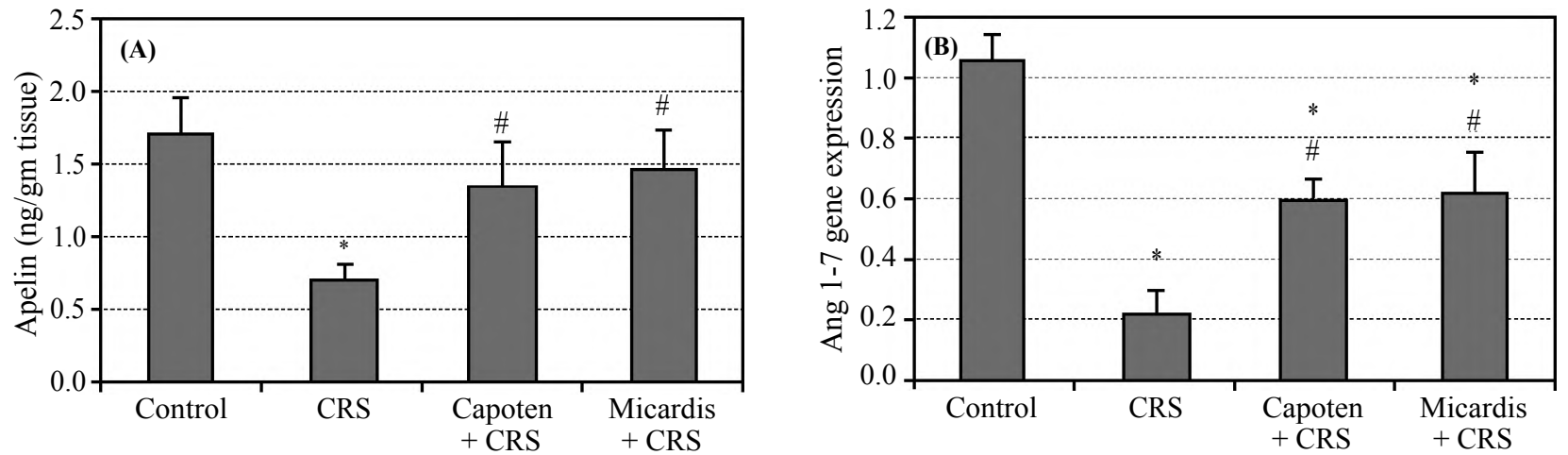

Fig. (2): (A): Apelin (ng/gm tissue), (B) Ang 1-7 gene expression in the four studied groups (n=6).

Each vertical bar represents the mean $\pm \mathrm{SD}$

*: Means significantly different compared to control group $(p<0.001)$

\#: Means significantly different compared to CRS group $(p<0.001)$ 


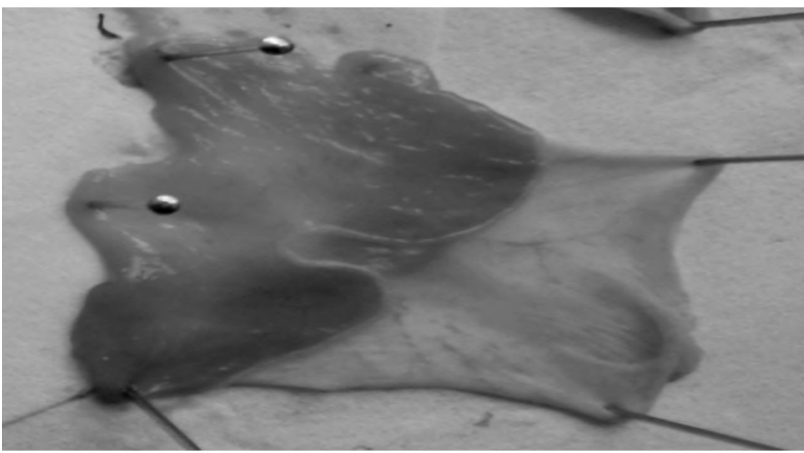

(A)

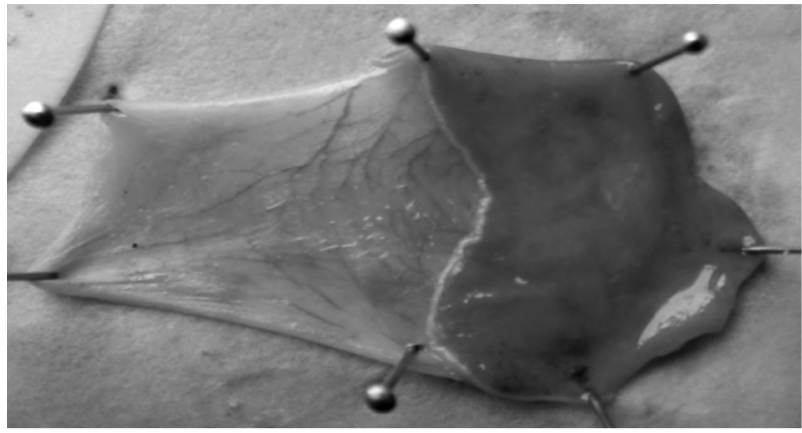

(C)

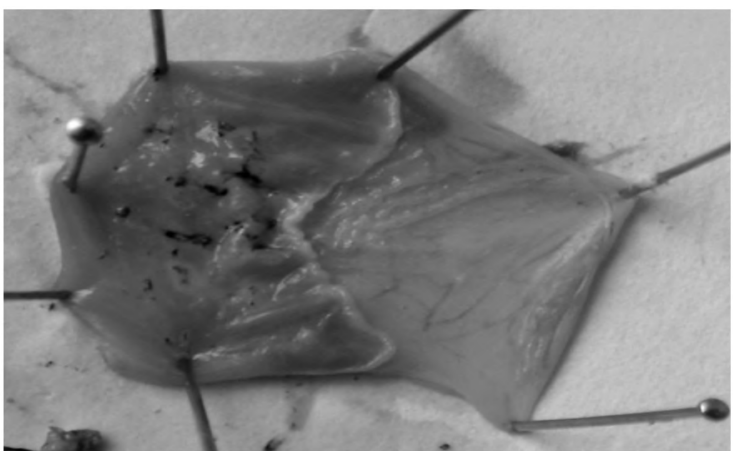

(B)

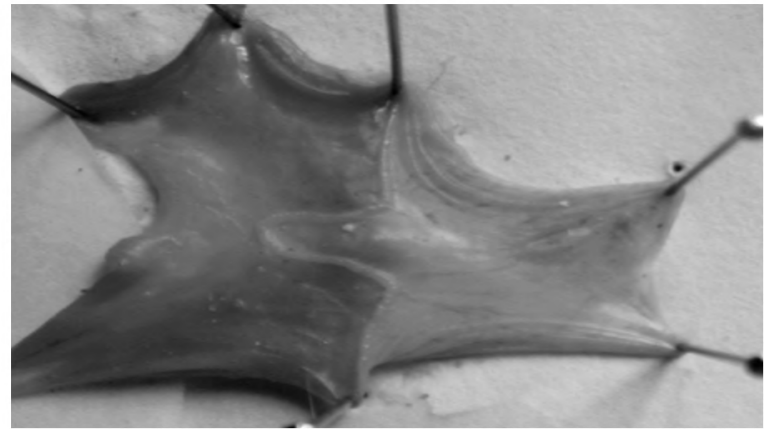

(D)

Fig. (3): Gross picture of gastric mucosa of (A): Control. (B): CRS. (C): Capoten + CRS and (D): Micardis + CRS groups.

(A)

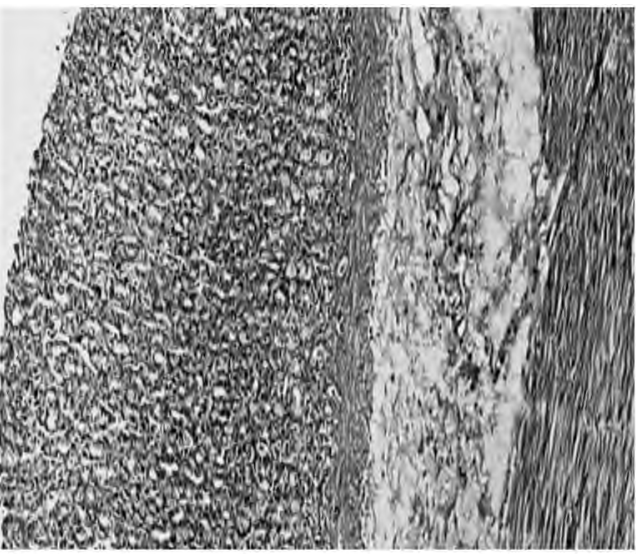

(C)

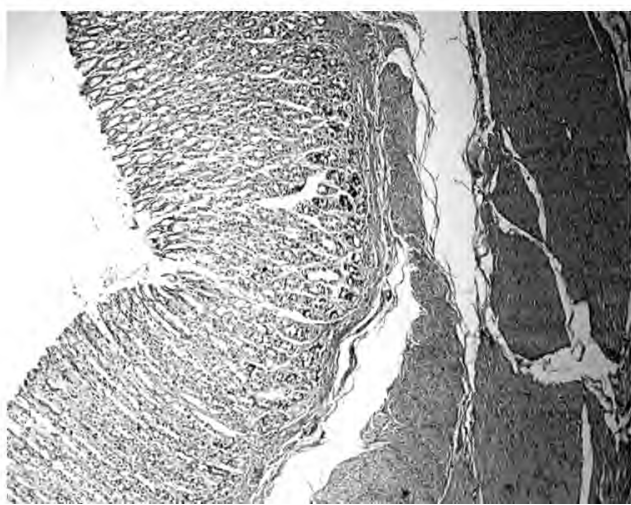

(B)

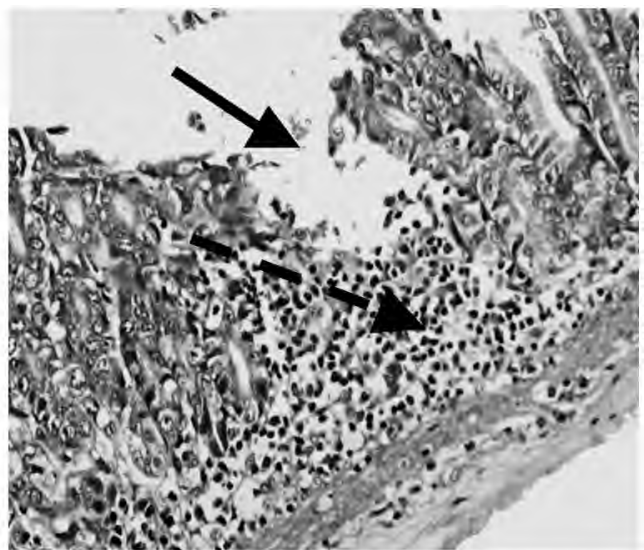

(D)

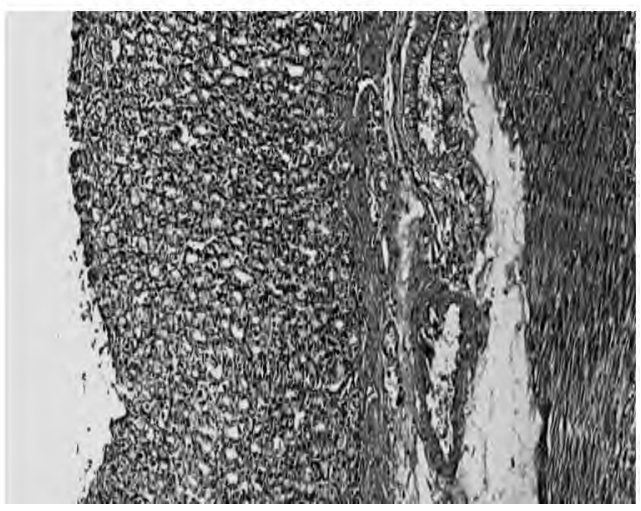

Fig. (4): Microscopic picture of gastric mucosa of the studied groups stained with H \& E (200X original magnification). (A): Control group: Shows intact gastric mucosa with no evidence of inflammation. (B): CRS group: Shows ulceration of gastric mucosa (continuous arrow) with underlying acute inflammatory cellular infiltration of lamina propria (interrupted arrow). (C): Capoten + CRS, and (D): Micardis + CRS groups: Show gastric wall with unremarkable pathological changes. 


\section{Discussion}

In the present study, we exposed the pyloric ligated immobilized rats to cold stress which resulted in gastric ulceration. The ulcer index, total acidity and MDA level of the stomach were significantly elevated with significant reduction in gastric mucin, PGE2 and NO content of the gastric mucosa compared to control group. It was reported that stress-induced excessive secretion of gastric acid and its stasis; are essential for the development of stress ulcers [23]. Exposure to cold leads to severe impairment of gastric mucosal blood flow and decreased mucus secretion $[24,25]$. Also stress encourages oxygen-derived free radicals formation which in turn provokes ischemic tissue damage [26]

Our study demonstrated that treatment with either capoten or micardis for 14 days prior to exposure to CRS significantly improved the gastric ulcer index, reduced the gastric acidity, MDA and COX2 gene expression and elevated the gastric mucin, NO and PGE2 content. It is well established that prostaglandins have various anti-ulcerogenic effects as they lead to increase in gastric mucin production, proliferation of gastric mucosa, angiogenesis, and play a role in regulation of gastric acid secretion [27]. Moreover, no was recognized to inhibit gastric acid secretion and play a very crucial role in gastric ulcer healing through vasodilatation and improving gastric blood flow [28]

Garrison et al., [29] documented that the mode of action of capoten, is probably through reinforcement of the gastric mucosal barrier and improving the blood flow via inhibition of Ang II formation. The decrease of gastric acidity by capoten may be due to the presence of a sulfhydryl group in the capoten [30] or through increased gastric PGE2 [31]. As capoten is a competitive inhibitor to kininase II, so, it causes a rise in plasma bradykinin level which will increase the production of prostaglandins. Also capoten displays an antioxidant activity through scavenging free radicals and impeding lipid peroxidation and MDA production [31].

The protective effect of micardis in CRS model is two folds; AT 1 receptor blocker [32] and PPARy stimulator [33]. Activation of PPAR-y improves gastric circulation through the increased production of no [34], increases mucin content of gastric mucosa and stimulation of glutathione production which acts as cofactor in some steps of PGs synthesis [35]. Moreover, previous studies demonstrated the anti-inflammatory effects of PPAR-y agonist via inhibition of pro-inflammatory cytokines production such as TNF- $a$, IL-1B, and IL-6 and over expression of heat shock protein 70 [34].

The literature provides strong evidence regarding the gastroprotective effect of apelin as described above. A previous immunohistochemical study revealed that apelin, produced by parietal cells, acts as a negative regulator of gastric acidity. It binds APJ receptors on enterochromaffin like cells and inhibits histamine release; hence decreasing gastric acidity [36]

It has been reported that apelin/APJ system antagonizes actions of Ang II by many mechanisms. Apelin stimulates heterodimerization of APJ and AT1 receptors, thereby, it downregulates the detrimental actions of ang II mediated via AT1 receptor [37]. Also, apelin was found to upregulate ACE2 expression that acts on ang II liberating the active metabolite Ang 1-7 [38]. Ang 1-7 antagonizes Ang II actions through its anti-inflammatory, antiproliferative, anti-fibrotic and anti-apoptotic effects [39]. Previous studies showed that pretreatment of rats subjected to cold restrained stress by Ang 17 decreased gastric acidity and protected gastric mucosa against ulceration. This gastroprotective effect was attributed to the increase in gastric blood flow, no and PGE2 together with decreased oxidative stress and the pro-apoptotic factor caspase 3 $[40,41]$

Interestingly, the present work reported that the gastroprotective effects induced by inhibition of RAS either by the ACE-1 inhibitor (capoten) or the AT-1 blocker (micardis) were associated with a significant increase in apelin level and Ang 1-7 gene expression. Our results together with previous studies suggest the protective role of apelin against gastric injury. This gastroprotective effect could be partly mediated via increasing the gene expression of Ang 1-7.

In conclusion, this work provides strong evidence regarding the gastroprotective effects of ACE-1 inhibitors and AT-1 blockers against CRS induced ulcers. Further, our study highlights the crosstalk between RAS and apelin/APJ system in protection against gastric ulceration.

\section{References}

1- SUN H., LI R., XU S., LIU Z. and MA X.: Hypothalamic Astrocytes Respond to Gastric Mucosal Damage Induced by Restraint Water-Immersion Stress in Rat. Front. Behav. Neurosci., 10: 210, 2016.

2- MARTIN C. MICHEL, HANS R. BRUNNERC., CAROLYN FOSTERD and YONG HUOE.: Angiotensin II type 1 receptor antagonists in animal models of vascular, 
cardiac, metabolic and renal disease. Pharmacology \& Therapeutics, Volume 164, August Pages, 1-81, 2016.

3- SONNENBERG A.: Concordant occurrence of gastric and hypertensive diseases, Gastroenterology, 95: 42-8, 1988.

4- IAKUBOV A.V. and USMANOVA S.H.E.: Prophylactic use of angiotensin-converting enzyme inhibitors in indomethacin-induced ulcer and erosion lesions of the stomach, Lik. Sprava., (2): 47-9, 2004.

5- MORSY M., ASHOUR O., AMIN E. and ROFAEIL R.: Gastroprotective effects of telmisartan on experimentallyinduced gastric ulcers in rats, Pharmazie, 64: 590-4, 2009.

6- OLSZANECKI R., MADEJ J., SUSKI M., GEBSKA A., BUJAK-GIZYCKA B. and KORBUT R.: Angiotensin metabolism in rat stomach wall: Prevalence of angiotensin(1-7) formation, J. Physiol., Pharmacol., 60: 191-6, 2009.

7- WANG G., KUNDU R., HAN S., QI X., ENGLANDER E.W., QUERTERMOUS T. and GREELEY G.H. Jr.: Ontogeny of apelin and its receptor in the rodent gastrointestinal tract, Regul. Pept., 158: 32-9, 2009.

8- LV S.Y., YANG Y.J. and CHEN Q.: Regulation of feeding behavior, gastrointestinal function and fluid homeostasis by apelin, Peptides., 44: 87-92, 2013.

9- IZGUT-UYSAL V.N., GEMICI B., BIRSEN I., ACAR $\mathrm{N}$. and USTUNEL I.: The protective effect of apelin against water-immersion and restraint stress-induced gastric damage. J. Physiol. Sci., 64: 279-89, 2014.

10- SATO T., SUZUKI T., WATANABE H., KADOWAKI A., FUKAMIZU A., LIU P.P., KIMURA A., ITO H., PENNINGER J.M., IMAI Y. and KUBA K.: Apelin is a positive regulator of ACE2 in failing hearts, J. Clin. Invest., 123 (12): 5203-11, 2013.

11- DEBNATH P., GODE K,. DAS D. and SANYAL A.: Effects of propranolol on gastric secretion in albino rats, Br. J. Pharmacol., 51: 213-6, 1974.

12- KULKARNI M. and JUVEKAR A.: Attenuation of acute and chronic restraint stress-induced perturbations in experimental animals by Nelumbo nucifera Gaertn, Indian J. Pharm. Sci., 70: 327-32, 2008.

13- SANYAL A., PANDEY B. and GOEL R.: The effect of a traditional preparation of copper, tamrabhasma, on experimental ulcers and gastric secretion, J. Ethnopharmacol., 5: 79-89, 1982.

14- RAJKAPOOR B., ANANDAN R. and JAYAKAR B.: Anti-ulcer effect of Nigella sativa Linn. against gastric ulcers in rats B. Current. Science, (82) 2: 25, 2002.

15- WINZLER R.: Determination of serum glycoproteins. Methods Biochem. Anal., 2: 279-311, 1955.

16- FELDMAN M., SCHARSCHMIDT B.F., SLEISENGER M.H., SLEISENGER and FORDTRAN'S.: Gastric secretion; normal and abnormal, In: Gastrointestinal and Liver Disease: Pathophysiology/Diagnosis/Management, 6 th ed., Philadelphia, p., 587-603, 1998.

17- WILLS E.D.: Evaluation of lipid peroxidation in lipids and biological membranes. In: SNELL K. and MULLOCK B., eds. Biochemical toxicology: A practical approach, 1987.

18- MONTGOMERY H. and DYMOCK J.: The determination of nitrite in water. Analyst., 86: 414-6, 1961.
19- FERNÁNDEZ N., ALONSOS, VALERA I. and VIGO A.: "Mannose-containing molecular patterns are strong inducers of cyclooxygenase-2 expression and prostaglandin E2 production in human macrophages". J. Immunol., 174: 8154-62, 2005

20- SILVA A.P., FRAGOSO A., SILVA C., VIEGAS C., TAVARES N., GUILHERME P., SANTOS N., RATO F., CAMACHO A., CAVACO C., PEREIRA V., FAÍSCA M., ATAIIDE J., JESUS I. and NEVES P.: What is the role of apelin regarding cardiovascular risk and progression of renal disease in type 2 diabetic patients with diabetic nephropathy? Biomed. Res. Int., 247649. doi: 10.1155/ 2013/247649. Epub 2013 Sep. 9, 2013.

21- PFAFFI M.W.: A new mathematical model for relative quantification in real-time RT-PCR. Nucleic Acids Res. 29: e45, 2001.

22- CHAN Y.: Biostatistics 102, Quantitative Data = Parametric \& Non-parametric Tests, Singapore Med. J., 44 (8): 3916, 2003.

23- RITCHIE Jr. W.P.: Acute gastric mucosal damage induced by bile salts, acid and ischemia, Gastroenterology, 68 : 699-707, 1975.

24- ISHII M., SHIMIZU S., NAWATA S., KIUCHI Y. and YAMAMOTO T.: Involvement of reactive oxygen species and nitric oxide in gastric ischemia-reperfusion injury in rats: Protective effect of tetrahydrobiopterin, Dig. Dis. Sci., 45: 93-8, 2000.

25- OBST B., WAGNER S., SEWING K.F. and BEIL W.: Helicobacter pylori causes DNA damage in gastric epithelial cells. Carcinogenesis, 21: 1111-5, 2000.

26- COSKUN T., ALICAN I., YEGEN B.C., SAN T., CETINEL S. and KURTEL H.: Cyclosporin A reduces the severity of cold-restraint induced gastric lesions: Role of leukocytes, Digestion (56) 3: 214-9, 1995.

27- BRZOZOWSKI T., KONTUREK P. and KONTUREK S. "Role of prostaglandins in gastroprotection and gastric adaptation". J. Physiol. Pharmacol., 56: 33-9, 2005.

28- WHITTLE B., LOPEZ-BELMONTE J. and MONCADA, S.: "Regulation of gastric mucosal integrity by endogenous nitric oxide: Interactions with prostanoids and sensory neuropeptides in the rat". Br. J. Pharmacol., 99: 607-611, 1990.

29- GARRISON C.J., PEACH M.K. IN Gilman A.G., RAIL W.T., WIES S.A. and TAYLER PEDS: Renin and Angiotensin. The pharmacological basis of therapeutics. New York, Pergamon Press, 757-9, 1990.

30- BRZOZOWSKI T., MAGIEROWSKA K., MAGIEROWSKI M., PTAK-BELOWSKA A., PAJDO R., KWIECIEN S., OLSZANECKI R. and KORBUT R.: Recent Advances in the gastric mucosal protection against stressinduced gastric lesions. Importance of renin-angiotensin vasoactive metabolites, gaseous mediators and appetite peptides. Current Pharmaceutical Design; Volume 23, Issue 27, 2017.

31- ISMAIL N.M., IBRAHIM I.A., HASHIM N.B. and JAARIN K.: Effects of captopril on factors affecting gastric mucosal integrity in aspirin-induced gastric lesions in Sprague-Dawley rats, Arch. Med. Sci., 9 (6): 1132-7, 2013. 
32- UNGER T. and STOPPELHAAR M.: Rationale for double renin-angiotensinaldosterone system blockade, Am. J. Cardiol., 100: 25J-31J, 2007.

33- SCALERA F., MARTENS-LOBENHOFFER J., BUKOWSKA A., LENDECKEL U., TÄGER M. and BODEBÖGER S.M.: Effect of telmisartan on nitric oxideasymmetrical dimethylarginine system: Role of angiotensin II type 1 receptor gamma and peroxisome proliferator activated receptor gamma signaling during endothelial aging, Hypertension, 51: 696-703, 2008.

34- KONTUREK P.C., BRZOZOWSKI T., BURNAT G., SZLACHCIC A., KOZIEL J., KWIECIEN S., KONTUREK S.J. and HARSCH I.A.: Gastric ulcer healing and stress-lesion preventive properties of pioglitazone are attenuated in diabetic rats, Journal of Physiology and Pharmacology, 61 (4): 429-36, 2010.

35- TAREK A. and SAMAR S.E.: Effect of peroxisome proliferator- activated receptor-gamma (PPAR- y) ligands on gastric mucosal injury induced by ischemia/reperfusion in rats, Bull. Alex. Fac. Med., 42 (1), 2006.

36- LAMBRECHT N.W., YAKUBOV I., ZER C. and SACHS G.: Transcriptomes of purified gastric ECL and parietal cells: Identification of a novel pathway regulating acid secretion, Physiol. Genomics., 25: 153-65, 2006.

37- SIDDIQUEE K., HAMPTON J., MCANALLY D., MAY L. and SMITH L.: The apelin receptor inhibits the angi- otensin II type 1 receptor via allosteric trans-inhibition, Br. J. Pharmacol., 168 (5): 1104-17, 2013.

38- CHUN H.J., ALI Z.A., KOJIMA Y., KUNDU R.K., SHEIKH A.Y., AGRAWAL R., ZHENG L., LEEPER N.J., PEARL N.E., PATTERSON A.J., ANDERSON J.P., TSAO P.S., LENARDO M.J., ASHLEY E.A. and QUERTERMOUS T.: Apelin signaling antagonizes Ang II effects in mouse models of atherosclerosis, J. Clin. Invest., 118 (10): 3343-54, 2008.

39- BRZOZOWSKI T.: Role of renin-angiotensin system and metabolites of angiotensin in the mechanism of gastric mucosal protection, Current Opinion in Pharmacology, 19: 90-8, 2014.

40- MAGIEROWSKI M., JASNOS K., PAWLIK M., KRZYSIEK-MACZKA G., PTAK-BELOWSKA A., OLSZANECKI R., KWIECIEN S., KORBUT R. and BRZOZOWSKI T.: Role of angiotensin-(1-7) in gastroprotection against stress induced ulcerogenesis, the involvement of mas receptor, nitric oxide, prostaglandins, and sensory neuropeptides. J. Pharmacol. Exp. Ther., 347: 717-26, 2013.

41- A M.K., AZIZ N.M., E M.A. and RIFAAI R.A.: Possible contribution of nitric oxide and prostaglandin in the protective effect of angiotensin (1-7) against stress induced gastric ulceration in adult male albino rats, Bratisl. Lek. Listy., 117 (12): 715-21, 2016.

\section{التفاعل بين نظامى الريثين-أنجيوتنسين و (الأبيلين/مستقبلات الأبيلين)

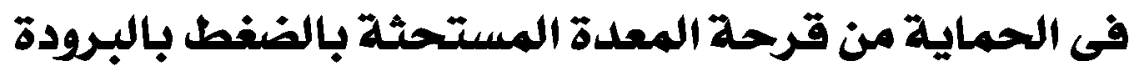 فى الفئران الذكور البالغين}

\footnotetext{
الخلفية: إن تنشيط نظام الرينين-أنجيوتنسين (راس) يعد إحدى الآليات الرئيسية المشاركة في تطوير قرحة المعدة المعتحثة بالضغوط. الهدف: تهدف هذه الدراسة إلى فحص تائثير مثبطات نظام الرينين-أنجيوتنسين في الحماية من قرحة المعدة والمستحثة بالضغوط والتفاعل

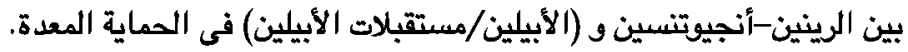

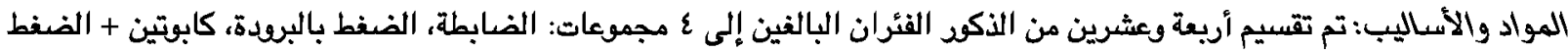

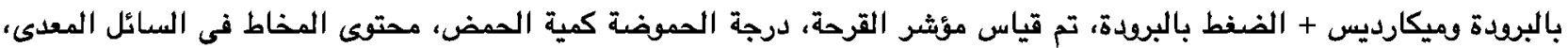

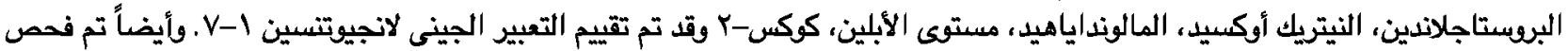

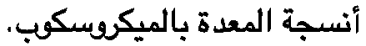

النتائج: المعالجة المسبقة للفئران أما مع كابوتين أو ميكارديس لمدة عا يوماً قبل إحداث قرحة المعدة بالضفط بالبروة أدى إلى إنخفاض

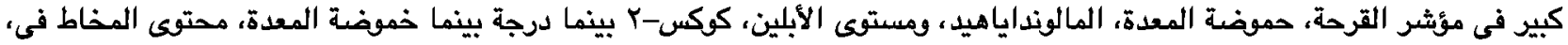

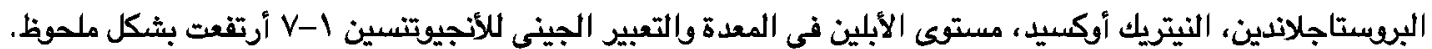

الخلاصدة: تشير النتائج التي توصلنا إليها إلى التكامل بين نظامي الرينين-أنجيوتنسين و (الأبيلين/مستقبلات الأبيلين) في الحماية من 